\title{
A diagnostic challenge: pyogenic granuloma or oral focal mucinosis
}

\author{
Siva Kumar $M_{1}{ }^{1}$ Hari Kumar ${ }^{2}{ }^{2}$ Vishalakshi Sivakumar, ${ }^{1}$ Sabitha Hari Kumar ${ }^{3}$
}

${ }^{1}$ Department of Maxillo Facial, Doctor Kamalkanadasan Dental Clinic, Chennai, Tamil Nadu, India

${ }^{2}$ Department of Oral Medicine and Oral Radiology, Rajas Dental College and Hospital, Tirunelveli, Tamil Nadu, India ${ }^{3}$ Dental Department, Jeba Dental Clinic, Nagercoil, Tamil Nadu, India

\section{Correspondence to}

Dr Hari Kumar M, drhari.omrd@gmail.com

Accepted 13 May 2015
CrossMark

To cite: Kumar M S, Kumar $\mathrm{M} \mathrm{H}$, Sivakumar $\mathrm{V}$, et al. BMJ Case Rep Published online: [please include Day Month Year] doi:10.1136/ bcr-2015-210150

\section{DESCRIPTION}

A 25-year-old female patient presented to the dental clinic with a painless gingival swelling in the right mandibular first molar (46) region (figure 1). The swelling had been present for the past 4 months. The medical and surgical histories were unremarkable.

Intraoral examination revealed a reddish, sessile, firm, well-defined mass measuring $1.0 \mathrm{~cm}$ at its greatest dimension (figure 2). Panoramic radiographic

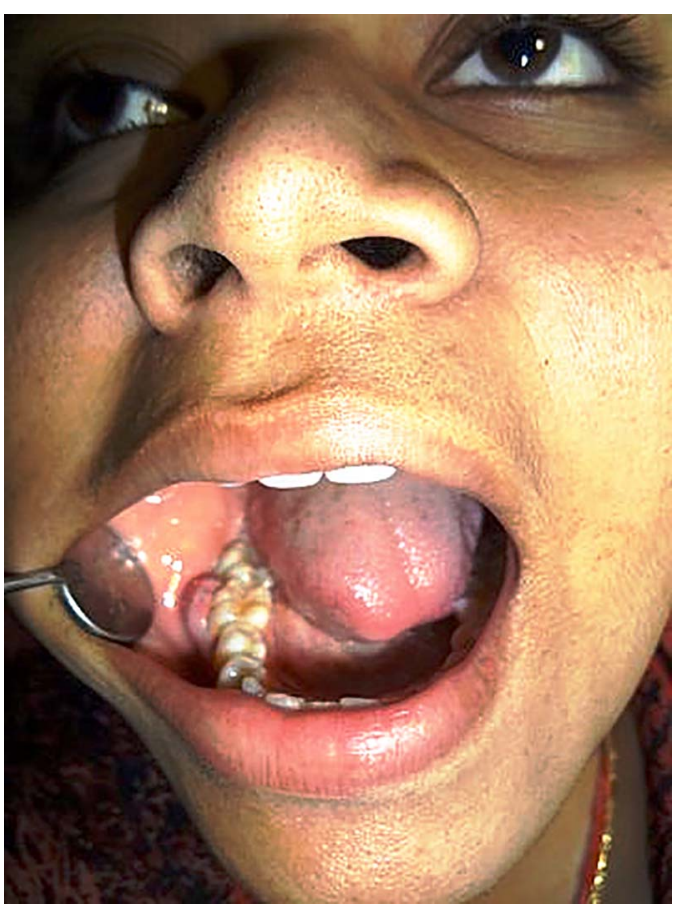

Figure 1 Preoperative clinical photograph showing gingival swelling in relation to right mandibular first molar.

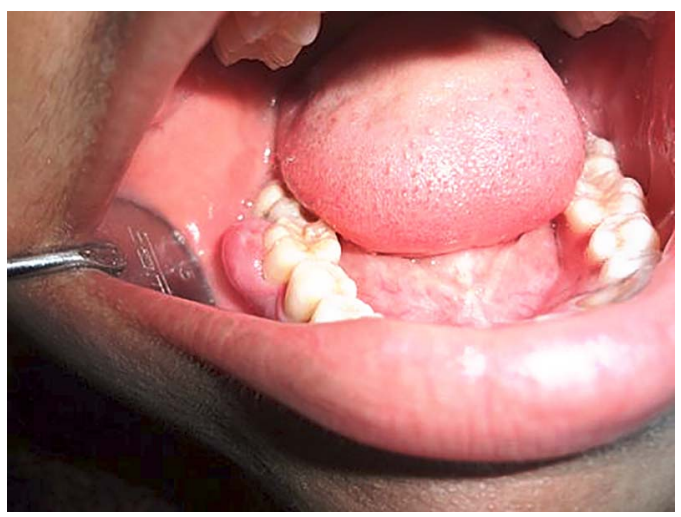

Figure 2 Intraoral examination shows a sessile, firm, well-defined mass in relation to 46 region. examination showed no alterations in the underlying bone or in the adjacent teeth (figure 3). The first clinical impression at examination was that of pyogenic granuloma, irrational fibroma. Surgical excision of the lesion under local anaesthesia was planned. After administrating inferior alveolar nerve block on the right side, complete excision of the lesion was performed with a scalpel number 15 . Minimal bleeding was encountered, which was controlled with a pressure pack. The surgical wound was sutured with 3-0 vicryl.

The excised lesion was sent for histopathological examination. The H\&E stained microscopic slide

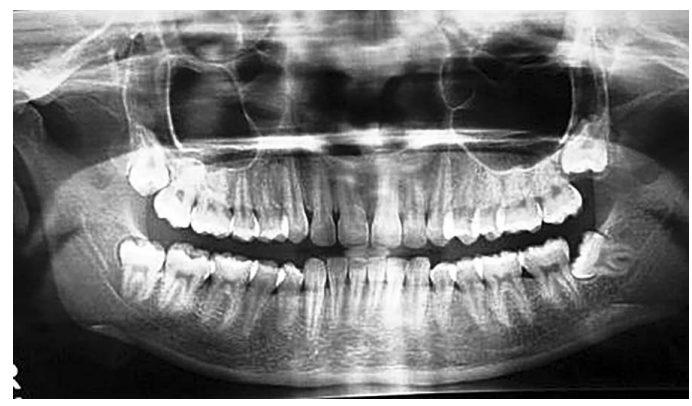

Figure 3 Panoramic radiographic examination shows no alterations in the underlying bone or in the adjacent teeth.

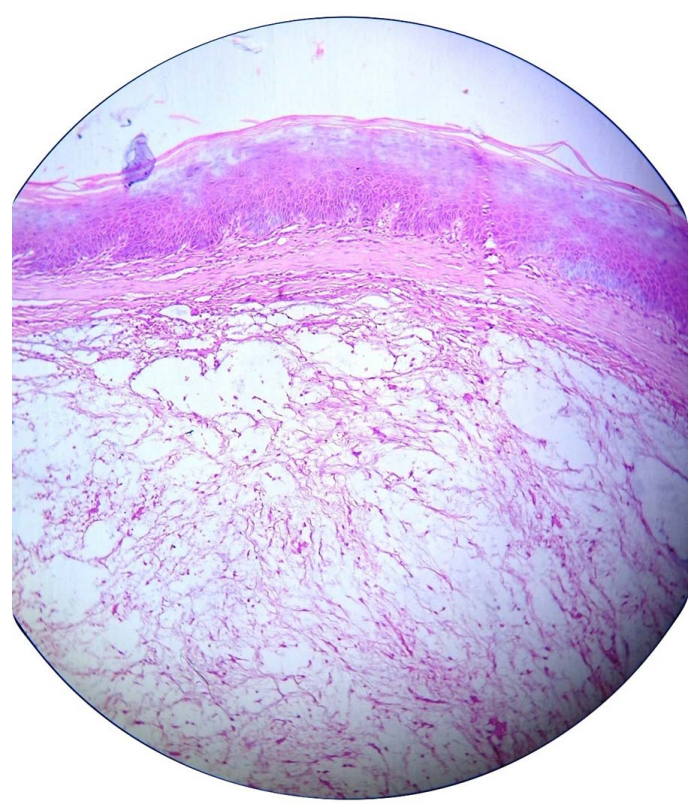

Figure 4 Photomicrograph showing parakeratinised stratified surface squamous epithelium with myxomatous stroma. 
revealed parakeratinised stratified surface squamous epithelium in association with a nodule of myxomatous tissue associated with spindle cells (figure 4). Based on the microscopic findings, the final diagnosis was oral focal mucinosis (OFM).

OFM is an uncommon clinicopathological condition that is considered to be the oral counterpart of cutaneous focal mucinosis (CFM). ${ }^{1}$ OFM has no distinctive clinical features and is most often clinically thought to be fibroma, pyogenic granuloma, mucocele or similar lesions. ${ }^{2}$

\section{Learning points}

Oral focal mucinosis (OFM) is a rare disease of unknown aetiology, and most commonly occurs in adult women; it has a slight predilection for the keratinised mucosa directly overlying the bone.

- OFM has no characteristic features and is most commonly diagnosed clinically as irritational fibroma, pyogenic granuloma, or mucocele. The diagnosis is based on histopathological examination only.
The lesions are difficult to clinically diagnose, as there are no clinically distinctive features. The histological features are always the basis for diagnosis. ${ }^{1}$ OFM is treated with surgical excision, after which it rarely recurs. ${ }^{2}$

In this case, the diagnosis of OFM was based on histological examination. After 1 year follow-up, the patient showed no signs of recurrence.

Contributors SKM and HKM contributed to diagnosis of the patient, acquisition of the data, and conceptualising, drafting and revision of the manuscript. VS contributed to diagnosis of the patient, acquisition of data, and conceptualising and revision of the manuscript. SHK contributed to diagnosis of the patient, and conceptualising, drafting and revision of the manuscript. All the authors gave their approval for the final version of the manuscript.

Competing interests None declared.

Patient consent Obtained.

Provenance and peer review Not commissioned; externally peer reviewed.

\section{REFERENCES}

1 Bharti $V$, Singh J. Oral focal mucinosis of palatal mucosa: a rare case report. Contemp Clin Dent 2012;3:S214-18.

2 Ena S, Nadellamanjari, Chatterjeeanirban, et al. Oral focal mucinosis: a rare case report of two cases. Ethiop J Health Sci 2013;23:178-82.

Copyright 2015 BMJ Publishing Group. All rights reserved. For permission to reuse any of this content visit http://group.bmj.com/group/rights-licensing/permissions.

BMJ Case Report Fellows may re-use this article for personal use and teaching without any further permission.

Become a Fellow of BMJ Case Reports today and you can:

- Submit as many cases as you like

- Enjoy fast sympathetic peer review and rapid publication of accepted articles

- Access all the published articles

- Re-use any of the published material for personal use and teaching without further permission

For information on Institutional Fellowships contact consortiasales@bmjgroup.com

Visit casereports.bmj.com for more articles like this and to become a Fellow 